\title{
ANTI-TARNISH SILVER ALLOYS IN SYSTEM Ag-Cu-Zn-Si WITH THE ADDITION OF ALUMINUM
}

\author{
Marija Korać $^{1 *}$, Stevan Dimitrijevic ${ }^{2}$, Kemal Delijić $^{3}$, Željko Kamberović $^{1}$ \\ ${ }^{1}$ Faculty of Technology and Metallurgy, University of Belgrade, Serbia \\ ${ }^{2}$ Innovation center of the Faculty of Technology and Metallurgy in Belgrade \\ Ltd, Serbia \\ ${ }^{3}$ Faculty of Metallurgy and Technology, University of Montenegro, Montenegro
}

Received 27.09.2018

Accepted 03.10.2018

\begin{abstract}
This paper presents investigations of aluminum addition influence on the corrosion characteristics of the sterling silver Ag-Cu-Zn-Si alloys. The procedure for obtaining Ag$\mathrm{Cu}-\mathrm{Zn}$-Al-Si alloys in small ranges of predefined composition was also presented. Open circuit potential measurements, linear polarization resistance method and potentiodynamic polarization tests were employed to determine corrosion characteristics of the alloys. The materials were tested in a $0.01 \mathrm{M}$ sodium sulfide solution. It was shown that the addition of aluminum improves sulfidization resistance and corrosion characteristics. Best results are achieved for the alloy with the following composition $92.5 \% \mathrm{Ag}, 1.9 \% \mathrm{Cu}, 3.7 \% \mathrm{Zn}, 1.6 \% \mathrm{Al}$ and $0.3 \% \mathrm{Si}$.
\end{abstract}

Keywords: anti-tarnish silver; alloy; corrosion resistance; sulfidization; $\mathrm{Ag}-\mathrm{Cu}-$ Zn-Al-Si system.

\section{Introduction}

Tarnishing of metals and alloys is a corrosion process manifested by the appearance of dark areas at material surface, an undesirable property in jewelry making. Main factors of surface tarnishing in silver and its alloys are numerous, but they could be classified according to compound types causing tarnishing. Leading groups are compounds containing sulfur, chlorine, and nitrogen [1,2]. Besides the concentration of gases containing the elements above, significant influence has physical factors like temperature, humidity, and illumination $[3,4]$. Reactions which lead to tarnishing are followed by oxidation reactions with atmospheric oxygen, which is confirmed by researches of tarnishing mechanisms $[5,6]$.

\footnotetext{
*Corresponding author: Marija Korać, marijakorac@tmf.bg.ac.rs
} 
The first research on silver tarnishing and development of anti-tarnishing alloys were conducted in 1927 by joint efforts of the Bureau of mines and Bureau of standards, USA [7]. Their results indicate that from the two-component alloys, the best antitarnishing properties have alloys with zinc or cadmium. Almost hundred years ago they concluded that two-component alloys could not fulfill all required properties for increased corrosion resistance and that they could be only used as base alloys for three- or fourcomponent alloys.

Historically speaking, the first tested three-component alloys were based on chromium, nickel, tantalum, and zinc. For dissolving of nickel in silver $\mathrm{Sb}, \mathrm{Sn}, \mathrm{Zn}$ or $\mathrm{Cd}$ were used. From today's point of view, $\mathrm{Sb}$ and $\mathrm{Cd}$ are not acceptable as toxic metals. In research of that time, best results showed alloys based on zinc and silicon, and one of the first commercially available anti-tarnish silver alloys were $\mathrm{Ag} 92.5 \mathrm{Si} 4 \mathrm{Cd} 3.5$ and Ag93Zn6.5Na0.5 [7].

Since then several alloys systems have been patented resistant to tarnishing and general corrosion. In the last decades of the XX century, silver content in most alloys did not match requirements of sterling silver, and it was usually under 90\% [8-10]. Beside this fact, in its composition, these alloys contained toxic antimony [8]. Later, in order to fulfill the jewelry requirement for sterling silver, patented alloys had a minimum of 92.5 $\%$ of silver [11-14]. These alloys were mostly multi-component systems, and often included five or more alloying elements with the addition of several more microalloying components. Addition of this number of alloying elements is not favorable from the production point, and for accurate prediction and repetition of properties and composition.

Also, most of these alloys contain nickel, which can cause contact dermatitis [15], tin which is very hard to recycle by conventional hydrometallurgical methods $[16,17]$, precious metals, like palladium or gold, which are very expensive or metals such as titanium or niobium which are not only rare, but also have high melting points.

In scientific literature influence of individual elements or their combination of mechanical properties, corrosion resistance and tarnishing [18-20] were investigated but showed limited success.

The significant ternary system in this area is $\mathrm{Ag}-\mathrm{Cu}-\mathrm{Zn}$ which is rarely used as such but as a base for a set of alloys. Addition of silicon in concentrations ranging from 0.02 to $0.2 \%$ makes silver alloys with copper and zinc more resistant to tarnishing [20].

Another alloy, which is only commercially available ternary system, is $\mathrm{Ag}-\mathrm{Cu}-\mathrm{Ge}$. This is at the same time the most straightforward system where part of the copper is replaced with germanium in sterling silver. Commercial $\mathrm{Ag}-\mathrm{Cu}-\mathrm{Ge}$ ternary alloy is protected with patent [21] and have the following composition: $93.5-95.5 \% \mathrm{Ag}, 0.5-3.0 \%$ $\mathrm{Ge}$, and rest $\mathrm{Cu}$. The main disadvantage of $\mathrm{Ge}$ is toxic vapor developing during the production of these alloys. Also its prices very high, and even with some fluctuations, significantly higher than silver [22] and it is classified as critical raw material in EU and USA [23, 24] which do not have primary raw materials and its recycling is limited [22].

Besides germanium, silicon is an element extensively used as an alloying element for an increase of tarnish resistance of silver $[2,11,18,19]$. Silicon has higher affinity to oxygen than silver, copper, and zinc. It is used as antioxidizer of melt, preventing the development of dark oxides by forming of shiny $\mathrm{SiO}_{2}$ layers on the surface. If used in a proper concentration, silicon with zinc can increase the tarnish resistance of $\mathrm{Ag}-\mathrm{Cu}$ alloys [25]. Tarnish resistance is increased with an increase on silicon addition but is highly 
dependent on silver concentration, so the influence is low at alloys with $92.5 \% \mathrm{Ag}$, and more pronounced at alloys with 95\% [19]. This conclusion is more related to a copper concentration which in an amount over $5 \%$ significantly reduces corrosion resistance regardless of silicon addition.

As said, alloys in system Ag-Cu-Zn-Si are used as the base for tarnish resistant commercial alloys. To this quaternary diagram usually, some microalloying component is added for crystal grain refining. Zinc is added up to $2.5 \%$, and silicon maximally $0.2 \%$ [25]. Alongside the zinc concentration in the alloy, the ratio of $\mathrm{Cu} / \mathrm{Zn}$ is important; a higher ratio considerably increases tarnish resistance at alloys with $94 \%$ of $\mathrm{Ag}$, but it is not that high. Generally, Ag-Cu-Zn alloy is favorable from a recycling point, and several technologies for its production have been developed [26].

Indium is one of the metals often used as alloying element replacing zinc, but with limited success regarding mechanical properties. Alloys in system Ag-In-Zn-Sn were among the first patented anti-tarnish alloys [8], but the price of indium is similar to silver price and wouldn't lower the cost of final alloy. In the same time, the addition of indium decreases the hardness of the material, so its addition must be limited and well optimized. Tin in this system is unfavorable from recycling point.

Aluminum could also be added along indium. Patented alloys with aluminum usually contain In, Sn and $\mathrm{Cd}$ [9] or In, Sn and Ni [12], which are, in both cases, undesirable from previously mentioned reasons.

Previous research of authors [27, 28] was focused on investigating the influence of silicon addition to standard sterling silver alloy and replacement of copper with silicon in the range from 0.05 to $0.3 \%$ [27] and additionally replacement of $1 \%$ of copper with zinc [28].

Presented research is focused on the development of new material, series of alloys, which satisfies requirements for corrosion resistance, atmospheric corrosion, and corrosion in solutions with sulfide ions. The central postulate is that new material has higher corrosion resistance than standard sterling silver alloy.

About presented patent and scientific literature, for the development of new material following was taken into account:

- the new material does not contain precious metals (gold or platinum group metals), rare earth (lanthanides), critical metals $(\mathrm{Ge}, \mathrm{In})$ or other components which could increase the price of the alloy or their availability is limited,

- alloys do not contain allergens, or in another way, incompatible biological materials like $\mathrm{Ni}$ or $\mathrm{Co}$, and especially don't contain toxic heavy metals $(\mathrm{Pb}$, $\mathrm{Cd}, \mathrm{Tl}, \mathrm{Sb}$ ) or metalloids ( $\mathrm{Se}, \mathrm{Te}$ ),

- alloys are designed to be suitable for recycling, and therefore do not contain any process-complicating metals, such as tin,

- alloys do not contain refractory metals $(\mathrm{Nb}, \mathrm{Ta}, \mathrm{Mo}, \mathrm{W}, \mathrm{Re})$ or refractory metals in a broader sense ( $\mathrm{Hf}, \mathrm{Cr}, \mathrm{Ti}, \mathrm{V}, \mathrm{Zr}$ ), which are either expensive as components and additionally increase the price of the production process.

\section{Experimental part}

The investigation aimed to obtain a series of sterling alloys in $\mathrm{Ag}-\mathrm{Cu}-\mathrm{Zn}-\mathrm{Al}-\mathrm{Si}$ system, with the precisely defined chemical composition in order to determine corrosion characteristics in sulfide media. 
For designing new materials, several rules were established:

- silver content is $92.5 \%$

- silicon content is $0.3 \%$

- aluminum is added in a range from 0.9 to $3.0 \%$

- the ratio of $\mathrm{Zn} / \mathrm{Cu}$ is 2, and it was constant.

Target compositions of new anti-tarnish silver alloys are presented in Table 1.

Table 1. Target compositions of new anti-tarnish silver alloys.

\begin{tabular}{lccccc}
\hline \multirow{2}{*}{ Label } & \multicolumn{5}{c}{ Composition, wt.\% } \\
& $\mathrm{Ag}$ & $\mathrm{Cu}$ & $\mathrm{Zn}$ & $\mathrm{Al}$ & $\mathrm{Si}$ \\
\hline $\mathrm{AgCu} 2.1 \mathrm{Zn} 4.2 \mathrm{Al} 10.9 \mathrm{Si} 0.3$ & 92.50 & 2.10 & 4.20 & 0.90 & 0.30 \\
$\mathrm{AgCu} 1.9 \mathrm{Zn} 3.7 \mathrm{Al1} .6 \mathrm{Si0} 0.3$ & 92.50 & 1.9 & 3.7 & 1.60 & 0.30 \\
$\mathrm{AgCu} 1.6 \mathrm{Zn} 3.3 \mathrm{~A} 12.3 \mathrm{Si} 0.3$ & 92.50 & 1.6 & 3.3 & 2.30 & 0.30 \\
$\mathrm{AgCu} 1.4 \mathrm{Zn} 2.8 \mathrm{Al} 3 \mathrm{Si} 0.3$ & 92.50 & 1.40 & 2.80 & 3.00 & 0.30 \\
\hline
\end{tabular}

Starting raw materials for the production of new tarnish resistant silver alloys were: pure metals ( $\mathrm{Ag}, \mathrm{Zn}$, and $\mathrm{Cu}$ ) and master alloys (Al-Si, $\mathrm{Al}-\mathrm{Zn}, \mathrm{Cu}-\mathrm{Si}$, and $\mathrm{Cu}-\mathrm{Zn}$ ).

Used master alloys, exclusively two-component systems, were specially produced for this experiment, and had following compositions:

1. Al-Si; eutectic alloy was made with $12 \% \pm 1 \% \mathrm{Si}$, total impurities $<0.15 \%$.

2. Al-Zn; $\mathrm{Zn}$ in the range $78 \% \pm 1 \%$ and $\mathrm{Al}$ to $100 \%$, total impurities $<0.1 \%$.

3. $\mathrm{Cu}-\mathrm{Si} ; \mathrm{Si}$ in the range $10 \% \pm 1 \%$ and $\mathrm{Cu}$ to $100 \%$, total impurities $<0.15 \%$.

4. $\mathrm{Cu}-\mathrm{Zn} ; \mathrm{Zn}$ in range $28 \% \pm 1 \%$, total impurities $0.1 \%$.

All used metals were purity minimum $99.9 \%$.

Production of new material was conducted through two phases:

The first phase was the production of master alloys; smelting in an induction furnace under a protective atmosphere (argon) and casting under vacuum. Casting began 2 min after reaching the melting temperature for all four alloys.

Pure metals were added in some excess for master alloy production, i.e.

- AlSi12 is obtained by adding $\mathrm{Al}$ and $\mathrm{Si}$ in the charge in ratio corresponding desired alloy, aluminum was added in excess $0.5 \%$, and silicon $0.2 \%$ due to the expected melting burnout. Melting temperature of charge was $650^{\circ} \mathrm{C}$.

- $\mathrm{AlZn} 78$ is obtained by adding $\mathrm{Al}$ and $\mathrm{Zn}$ in the charge in ratio corresponding desired alloy, aluminum was added in excess $0.5 \%$, and zinc $0.2 \%$ due to the expected melting burnout. Melting temperature of charge was $550^{\circ} \mathrm{C}$.

- CuSi10 is obtained by adding $\mathrm{Cu}$ and $\mathrm{Si}$ in the charge in ratio corresponding desired alloy, copper was added in excess $0.5 \%$, and zinc $0.2 \%$ due to the expected melting burnout. Melting temperature of charge was $1100^{\circ} \mathrm{C}$.

- $\mathrm{CuZn} 28$ is obtained by adding $\mathrm{Cu}$ and $\mathrm{Zn}$ in the charge in ratio corresponding desired alloy, copper was added in excess $0.5 \%$, and zinc $6 \%$ due to the expected melting burnout. Melting temperature of charge was $1050^{\circ} \mathrm{C}$.

The second phase of the process was the production of final new alloys using master alloys from the first phase and pure metals when necessary. Type of materials used for the production of each alloy is presented in Table 2. 
Table 2. Type of materials used for the production of each anti-tarnish silver alloy.

\begin{tabular}{lccccccc}
\hline Alloy & $\mathrm{Ag}$ & $\mathrm{Cu}$ & $\mathrm{Zn}$ & $\mathrm{AlSi12}$ & $\mathrm{AlZn} 78$ & $\mathrm{CuSi10}$ & $\mathrm{CuZn} 28$ \\
\hline $\mathrm{AgCu} 2.1 \mathrm{Zn} 4.2 \mathrm{Al0.9Si0.3}$ & + & & + & + & & + & + \\
AgCu1.9Zn3.7Al1.6Si0.3 & + & & + & + & & + & + \\
AgCu1.6Zn3.3Al2.3Si0.3 & + & + & + & + & & & \\
AgCu1.4Zn2.8Al3Si0.3 & + & + & & + & + & & \\
\hline
\end{tabular}

Smelting of final alloys was performed in an induction furnace at a temperature of $980^{\circ} \mathrm{C}$. The process began by charging of silver, and then other metals and/or master alloys. Casting began 2 min upon reaching the desired temperature. Before casting graphite, molds were preheated to $250-350^{\circ} \mathrm{C}$. Alloys were cast under vacuum.

For comparison reasons, an alloy of classic sterling silver $(92.5 \% \mathrm{Ag}$ and $7.5 \%$ $\mathrm{Cu})$ was also cast.

\section{Results and discussion}

Analysis of the chemical composition

In order to prove that by applying the described method, alloys with required chemical composition could be produced, chemical analysis of final alloys was comprised of several methods, optimal for a specific element. So for analysis of $\mathrm{Ag}$ and $\mathrm{Si}$ gravimetric method was applied, ICP-OES analysis for $\mathrm{Cu}, \mathrm{Zn}, \mathrm{Al}$, and XRF method sterling silver calibration was used.

Table 3. presents the results of the chemical analysis as mean values from three measurements.

Table 3. The chemical composition of produced alloys.

\begin{tabular}{lccccc}
\hline \multirow{2}{*}{ Label } & \multicolumn{5}{c}{ Chemical composition, wt. \% } \\
& $\mathrm{Ag}$ & $\mathrm{Cu}$ & $\mathrm{Zn}$ & $\mathrm{Al}$ & $\mathrm{Si}$ \\
\hline $\mathrm{AgCu} 2.1 \mathrm{Zn} 4.2 \mathrm{Al} 10.9 \mathrm{Si0} 03$ & 92.50 & 2.10 & 4.20 & 0.90 & 0.30 \\
$\mathrm{AgCu} 1.9 \mathrm{Zn} 3.7 \mathrm{A11} .6 \mathrm{Si} 0.3$ & 92.50 & 1.87 & 3.73 & 1.60 & 0.30 \\
$\mathrm{AgCu} 1.6 \mathrm{Zn} 3.3 \mathrm{Al} 2.3 \mathrm{Si} 0.3$ & 92.50 & 1.63 & 3.27 & 2.30 & 0.30 \\
$\mathrm{AgCu} 1.4 \mathrm{Zn} 2.8 \mathrm{Al} 3 \mathrm{Si} 0.3$ & 92.50 & 1.40 & 2.80 & 3.00 & 0.30 \\
\hline
\end{tabular}

Results of chemical composition analysis presented in Table 3 show that differences between set and achieved alloy composition is negligible for alloys with 1.6 and $2.3 \% \mathrm{Al}$, and for alloys with 0.9 and $3 \% \mathrm{Al}$, there is no difference in designed and obtained composition.

The proposed method for production of new anti-tarnish silver alloys is suitable and provides adequate process control. Anticipated burnouts for individual elements were suitable.

\section{Determination of corrosion resistance}

Because primary cause of tarnishing, i.e., atmospheric corrosion, are sulfides, it is common practice to test the resistance to sulfidization by electrochemical methods in the $\mathrm{Na}_{2} \mathrm{~S}$ solution. The degree of surface tanning is the value of the corrosion current density $\left(\mathrm{j}_{\text {corr. }}\right)$. These two parameters are directly dependent: the lower $\mathrm{j}_{\text {corr. }}$ indicates less tanned 
surface. The density of the corrosion current was determined by the method of linear polarization resistance.

Electrochemical measurements were performed in a thermostatic conventional three-electrode cylindrical glass cell. The working electrode was made out of investigated silver alloys, and an alloy of the sterling silver, embedded in polyacrylic resin. For electrochemical experiments Gamry Reference 600 potentiostat/galvanostat/ZRA was used and for analysis of the electrochemical data and determining the corrosion parameters, a Gamry Echem Analyst software package.

The potential was measured concerning a saturated calomel reference electrode (SCE), and results are presented in Table 4. Contra electrode was the platinum sheet with an area of $2 \mathrm{~cm}^{2}$. Before each measurement, a sample was ground and then polished to a mirror finish with $0.3 \mu \mathrm{m}$ alumina powder. After polishing, the electrode was thoroughly washed with distilled water and degreased with absolute (99.8\%) ethanol. The experiments were performed at a temperature of $25 \pm 0.5^{\circ} \mathrm{C}$. The open circuit potential (OCP) was measured for a period of $3600 \mathrm{~s}$. The linear polarization resistance (LRP) was measured at potentials of $\pm 20 \mathrm{mV}$ about OCP with the potential rate change of $0.125 \mathrm{mV} / \mathrm{s}$. The Tafel polarization curves were measured at the potentials of $\pm 200 \mathrm{mV}$ about OCP at the potential change rate of $1.0 \mathrm{mV} / \mathrm{s}$. Tafel's method [29] was used to determine the coefficient from the Stern-Geary equation. Operating solution was a solution of $\mathrm{Na}_{2} \mathrm{~S}$, concentration $0.01 \mathrm{~mol} / \mathrm{dm}^{3}$. For the preparation of the solution $\mathrm{Na}_{2} \mathrm{~S}$ p.a. quality and double distilled water, conductivity $<1 \mu \mathrm{S} / \mathrm{cm}$ were used.

Table 4. Corrosive parameters in $0.01 \mathrm{~mol} / \mathrm{dm}^{3} \mathrm{Na}_{2} \mathrm{~S}$ solution at $25^{\circ} \mathrm{C}$ determined by LPR method.

\begin{tabular}{lcccc}
\hline Alloy & $\begin{array}{c}\text { The coefficient of } \\
\text { Stern-Geary } \\
\text { equation }(\mathrm{B}), \mathrm{mV}\end{array}$ & $\begin{array}{c}\text { Polarization } \\
\text { resistance Rp, } \\
\mathrm{k} \Omega \cdot \mathrm{cm}^{2}\end{array}$ & $\begin{array}{c}\text { Corrosion } \\
\text { current density } \\
(\text { jcorr. }), \mu \mathrm{A} \cdot \mathrm{cm}^{-2}\end{array}$ & $\begin{array}{c}\text { Corrosion } \\
\text { potential } \\
\left(\mathrm{E}_{\text {corr. }}\right), \mathrm{mV}\end{array}$ \\
\hline $\mathrm{AgCu} 7.5($ referent alloy) & 15.82 & 2.506 & 6.313 & +42.29 \\
$\mathrm{AgCu} 2.1 \mathrm{Zn} 4.2 \mathrm{Al0}$.9Si0.3 & 33.44 & 126.3 & 0.265 & -186.6 \\
$\mathrm{AgCu} 1.9 \mathrm{Zn} 3.7 \mathrm{Al1}$.6Si0.3 & 26.18 & 128.5 & 0.204 & -135.9 \\
$\mathrm{AgCu} 1.6 \mathrm{Zn} 3.3 \mathrm{Al} 2.3 \mathrm{Si} 0.3$ & 28.01 & 45.36 & 0.579 & -177.1 \\
$\mathrm{AgCu} 1.4 \mathrm{Zn} 2.8 \mathrm{Al} 3 \mathrm{Si} 0.3$ & 27.02 & 42.80 & 0.631 & -181.5 \\
\hline
\end{tabular}

As can be seen from Table 2, the corrosion current densities for all the investigated alloys are in the order of magnitude less than for the reference alloy of sterling silver. The alloy $\mathrm{AgCu} 1.4 \mathrm{Zn} 2.8 \mathrm{Al} 3 \mathrm{Si} 0.3$ with the lower corrosion resistance has precisely ten times lower $\mathrm{j}_{\text {corr. }}$, while the alloy $\mathrm{AgCu} 1.9 \mathrm{Zn} 3.7 \mathrm{Al1} .6 \mathrm{Si} 0.3$ has almost 30 times lower value of the $j_{\text {corr }}$ from the referent alloy. These results can be considered significant because of the relatively high concentrations of the sulfide ions in the solution.

The value of corrosion current increases with increasing $\mathrm{Al}$ concentration in the alloy, except alloy with $1.6 \%$ of $\mathrm{Al}$ which had the lower current than the alloy with $0.9 \%$ Al. Polarization resistance abruptly drops when the aluminum content exceeds $2 \%$, but the difference between $2.3 \%$ and $3 \% \mathrm{Al}$ in the alloy is relatively small. The measured values of the $\mathrm{j}_{\text {corr. }}$ in $\mathrm{Na}_{2} \mathrm{~S}$ solution (Table 2) are low in absolute terms (under $1 \mu \mathrm{A} \cdot \mathrm{cm}^{-2}$ ), which shows that for all investigated alloys the corrosion rate and consequently the degree of tanning of the surface have significantly lower values than for the sterling silver. This indicates that at the deficient concentrations of the sulfide ions, typical for the 
atmospheric corrosion, the corrosion rates could be even lower and suggests that the investigated alloys are very stable over a long period regarding tarnish. Comparison of obtaining results with previously investigated [28] alloys in Ag-Cu-Zn-Si system are presented in Figure 1.

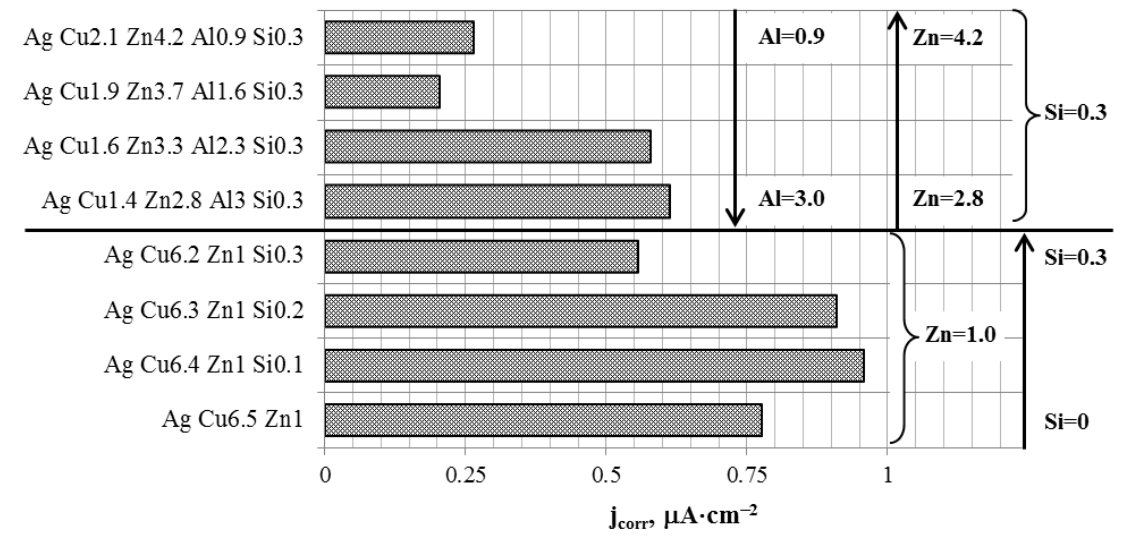

Fig. 1. Comparison of corrosion current density for anti-tarnish silver alloys with and without aluminum.

Presented results show that with the higher addition of aluminum $(2.3$ and $3 \%) \mathrm{j}_{\text {corr }}$ values are at the same level as alloy $\mathrm{AgCu} 6.2 \mathrm{Zn} 1 \mathrm{Si0}$.3. For a lower share of aluminum $(0.9$ and $1.6 \%)$, better results are obtained, and $\mathrm{j}_{\text {corr }}$ values decrease. The best results are achieved for the alloy with $1.6 \% \mathrm{Al}$. Besides the addition of aluminum, this could be attributed to the lower share of copper in alloy and higher zinc content.

\section{Conclusions}

Presented results show that the procedure for the production of new anti-tarnish silver alloys through the two-phase process method is suitable and provides adequate process control. Produced master alloys enabled the production of final alloys with composition almost the same as designed one.

As confirmation of anti-tarnishing properties of new alloys, measurement of corrosion current density measured in $0.01 \mathrm{~mol} / \mathrm{dm}^{3} \mathrm{Na}_{2} \mathrm{~S}$ solution showed that the corrosion current densities for all the investigated alloys are in the order of magnitude lower than for the reference alloy of sterling silver; alloy AgCu1.9Zn3.7Al1.6Si0.3 has almost 30 times lower value of the $\mathrm{j}_{\text {corr }}$ from the referent alloy.

Based on obtained results addition of aluminum in the range $0.9-3.0 \%$ to $\mathrm{Ag}-\mathrm{Cu}-$ $\mathrm{Zn}-\mathrm{Si}$ system is favorable from a corrosion point of view, and the best results are achieved for the alloy with $1.6 \% \mathrm{Al}$, label $\mathrm{AgCu} 1.9 \mathrm{Zn} 3.7 \mathrm{Al1} .6 \mathrm{Si} 0.3$. Subsequent detail microstructural investigation will explain the anti-tarnishing mechanism.

\section{Acknowledgment}

This work is the result of the technological development project TR34033 funded by the Ministry of Education, Science and Technological Development of the Republic of Serbia. 


\section{References}

[1] L. Gal-Or, In: Proceedings of The Santa Fe Symposium on Jewelry Manufacturing Technology, Ed. Dave Scheneller,1990, 123-130

[2] A. Basso, In: Proceedings of Jewelry Technology Forum the Santa Fe Symposium, 2010, 251-266

[3] C.J. Yang, C.H. Liang, X. Liu: Anti-Corros Method M, 54 (2007) 21-26

[4] J.P. Farney, G.W. Kammlott, T.E. Greadel: CorrosSci, 25 (1985) 133-143

[5] H. Kim: Mater Corros, 54 (2003) 243-250

[6] L. Volpe, P. J. Peterson: CorrSci, 29 (1989) 1179-1186

[7] L. Jordan, L.H. Grenell, H.K. Herschman, Tarnish Resisting Silver Alloys, Technologic papers of the bureau of standards, 348 (1927) 459-496

[8] H. Harigaya, K. Kasai, M. Asahina, U.S. Pat. No. 3,811,876 (1974)

[9] H.Sasaki, M. Nishiya, U.S. Pat. No. 5,021,214 (1991)

[10] M. Bernhard, U.S. Pat. No. 5,039,479 (1991)

[11] P. G. Johns, WO 2004106567 A1 (2004)

[12] A. Jones, F. Faverjon, R. Johnson, X. An, A. Hopkinson, J. Storey, WO 2006/106282 A1 (2006)

[13] D.P. Agarwal, G. Raykhtsaum, U.S. Pat. No. US 2006/0045792 A1 (2006)

[14] K.Fogel, U.S. Pat. No. US 2014/0003992 A1 (2014)

[15] I. Hirunyagrid, A. Chainpairot, E. Nisartanaporn, G. Lothongkum: Mater Test, 56 (2014) 649-655

[16] E. Nisaratanaporn, S. Wongsriruksa, S. Pongsukitwat, G. Lothongkum: Mater SciEng A, 445-446 (2007) 663-668

[17] S. Nisaratanaporn, E. Nisaratanaporn: Journal of Metals, Materials and Minerals, 12 (2003) 13-18

[18] X. Xiongzhia, B. Xiaojuna, C. Pengxu: Rare Metals, 31 (2012) 438-441

[19] D. Pope, H. R. Gibbens: CorrosSci, 8 (1968) 883-887

[20] H. E. Bennett, R. L. Peck, D. K. Burge, J. M. Bennet: J Appl Phys, 40 (1969) 3351 3360

[21] E. Protopopoff, P. Marcus: ElectrochimActa, 63 (2012) 22-27

[22] R. P. Turco, R. C. Whitfen, O. B. Toon, J. B. Pollack, P. Hamill: Nature, 283 (1980) 283-285

[23] T. E. Graedel, G.W. Kammlotf, J.P. Franey: Science, 212 (1981) 663-665

[24] E. Protopopoff, P. Marcus: CorrosSci, 45 (2003) 1191-1201

[25] E. Protopopoff, P. Marcus: ElectrochimActa, 51 (2005) 408-417

[26] P. R.Subramanian, J. H.Perepezko: J Phase Equilib, 14 (1993) 62-75

[27] Ž. Kamberović, J. S. Muzás, S. P. Dimitrijević, M. Korać, S. B. Dimitrijević, K. Delijić, In Proceedings 49th International October Conference on Mining and Metallurgy, 2017, 424-427

[28] S. P. Dimitrijević, V. Parežanin, Ž. Kamberović, M. Ranitović, M. Korać, S. B. Dimitrijević: Chem Ind Chem Eng Q, (2018)

[29] E. McCafferty: Corros Sci, 47 (2005) 3202-3215

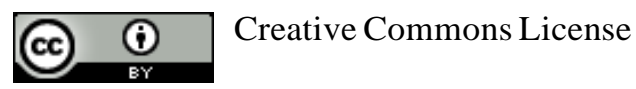

This work is licensed under a Creative Commons Attribution 4.0 International License. 